\title{
Mario Levrero e o desenho: por uma leitura por vir
}

Alexander Belivuk Moraes

UFSC

\section{Resumo}

A partir da recente publicação de algumas "proto-tirinhas", até o momento inéditas, do escritor uruguaio Mario Levrero tecem-se aqui algumas considerações em torno da importância e da natureza do desenho na sua produção literária. Assim, após detectar certa tendência "totalizante" em parte da fortuna crítica do autor, junto a um número cada vez maior de nomenclaturas possíveis para sua obra, tenta-se rastrear a partir dos citados esboços, e do capítulo 4 da sua nouvelle "Los muertos", uma outra arqueologia possível para sua literatura. Deste modo, utilizando algumas noções operatórias tais como "montagem", "escritura" e "imagem" tenta-se inscrever a produção do uruguaio dentro do denominado "regime estético" das artes na modernidade.

Palavras-chave: Mario Levrero; Desenho; Aisthesis; Jacques Rancière.

\section{Resumen}

A partir de la reciente publicación de algunas "proto-historietas", hasta el momento inéditas, del escritor uruguayo Mario Levrero se tejen aquí algunas consideraciones alrededor de la importancia de la práctica y la naturaleza del dibujo en su producción literaria. Así, detectada cierta tendencia "totalizante" en parte de la fortuna crítica del autor y de un número cada vez mayor de nomenclaturas posibles para su obra, se intenta rastrear a partir de los mencionados bocetos y del capítulo 4 de su novela corta "Los muertos" otra arqueología posible para su literatura. De este modo, utilizando algunas nociones operatorias tales como "montaje", "escritura" e "imagen" se intenta inscribir la producción del uruguayo dentro del denominado "régimen estético" de las artes en la modernidad.

Palabras clave: Mario Levrero; Dibujo; Aisthesis; Jacques Rancière. 
1. Cf. RAMA, Angel. (Org.)

"Prólogo". In: __. Aquí cien años de raros. Montevideo: Arca, 1966; FUENTES, Pablo. "Estudio posliminar. Levrero: el relato asimétrico". In: LEVRERO, Mario.

Espacios libres. Montevideo: Puntosur, 1987; OLIVERA, Jorge. Intrusismos de lo real en la narrativa de Mario Levrero. Tesis doctoral. Madríd: Universidad Complutense, 2008; MARTÍNEZ, Luciana.

"Mario Levrero: parapsicología, literatura y trance". Los límites de la literatura. Rosario: Centro de Estudios de Literatura Argentina, 2010, p.33-58; MONTOYA JUAREZ, Jesús. "Narraciones a base de imágenes: una lectura de Los muertos". In: Mario Levrero para armar. Jorge Varlotta y el libertinaje imaginativo. Montevideo: Trilce, 2013; DE ROSSO, Ezequiel. "Otra trilogía: las novelas policiales de Mario Levrero". In: . (Org.)

La máquina de pensar en Mario. Ensayos sobre la obra de Levrero. Buenos Aires: Eterna Cadencia, 2013.

2. Cf. GORTAZAR, Alejandro. "El canon nacional por dentro y por fuera. Felisberto Hernández en las antologías narrativas uruguayas (1930-1966)". Fragmentos, n.19. Florianópolis: Editora UFSC, p.31-45, 2000.

3. RAMA, Ángel. "Prólogo", 1966, p. 9.
Resulta quase um lugar comum na crítica, ao se referir à obra e a figura do escritor uruguaio Mario Levrero, apontar ao caráter "inclassificável" da sua produção dentro da narrativa rio-pratense do último quarto de século e começos do XXI. Efetivamente, epítetos como "rara", "fantástica", "imaginativa", "surreal”, "parapsicológica”, "ecfrástica”, "policial”" povoam o vocabulário da fortuna crítica que tenta se aproximar da obra do uruguaio como a um todo compreensível ou totalizável desde alguma perspectiva específica. No entanto, todas e cada uma destas iniciativas resultam insuficientes, desde o início, ao tentar abranger a partir de pressuposições genéricas, geracionais, estruturais ou fenomenológicas a prolífica e heteróclita produção de Levrero marcada por uma acentuada entropia, fruto de um experimentalismo com a linguagem e as formas do relato, mas, sobretudo, com a escritura.

Assim, a modo de exemplo das interpretações abrangentes e totalizantes que predominam na crítica sobre Mario Levrero, podemos mencionar a categoria dos "raros". De ascendência dariana, mas, tal qual levantada por Ángel Rama em 1966, esta noção funciona até hoje com peso considerável na hora de dividir águas nas letras uruguaias ao abrir passo mais tarde à figura de Felisberto Hernández que reestrutura ou fissura o cânone nacional ${ }^{2}$. Como colocava o crítico uruguaio no seu famoso prólogo:

No se trata de una línea de literatura fantástica que oponer a la realística dominante, según el esquema que cultivó la crítica argentina de hace dos décadas bajo la influencia del grupo Sur. Si bien apela con soltura a los elementos fantásticos, los utiliza al servicio de un afán de exploración del mundo. Así elude esos estereotipos fantásticos [...]. Con mayor rigor habría que hablar de una literatura imaginativa. Desprendiéndose de las leyes de la causalidad, trata de enriquecerse con ingredientes insólitos emparentados con las formas oníricas, opera con provocativa libertad y, tal como sentenciara el padre del género, [Lautreamont] establece el encuentro fortuito sobre la mesa de disección del paraguas y la máquina de coser $[. . .]^{3}$

Ao estabelecer filiações e paternidades claras a respeito de uma corrente literária que mais tarde alcançaria a Levrero, acreditamos que o termo "raro" serviu, a partir de Rama e apesar da aparente visibilidade outorgada aos seus integrantes, como contrapeso dialético para manter certa continuidade do cânone realista nacional dominante. Assim, ao detectar e admitir determinadas ramificações ou desvíos da norma, a categoria manteve um centro intocado desde um ponto de vista crítico ou histórico. Ao privilegiar certos modelos como "majoritários" ou "constantes" em detrimento de outros tomados como periféricos, 
“esporádicos" ou "subterráneos" estabiliza em um sistema único de referência e interpretação a potência, a pluralidade e o trânsito constante de saberes entre os discursos que a literatura configura como prática singular com a linguagem.

Citado brevemente com este exemplo certo problema endêmico "totalizador" em grande parte da crítica sobre Levrero, embasado numa preponderância de premissas realistas ou miméticas para a literatura, propomos para este trabalho uma noção operatória da "literatura não [como] um corpo ou uma sequência de obras, nem mesmo um setor de comércio ou de ensino, mas [como] o grafo complexo das pegadas de uma prática: a prática de escrever" ${ }^{\prime 4}$. Assim, entendemos a escritura como espaço extraterritorial do devir no cruzamento entre um sistema de significação definido em forma contrastiva (a linguagem) e o investimento de um sujeito do desejo no discurso, cuja enunciação resulta sempre instável ou deslocada pela intervenção do Outro, a marca da lei e do Inconsciente. Como num espelho, a imagem sempre diferida de um si mesmo no jogo metafórico e metonímico da linguagem trabalha sempre "em falso" em torno de um objeto impossível de representar, vazio, lugar da falta onde emerge o sujeito desejante e a História. Como se colocava desde as páginas da revista Literal em 1973:

La paradoja del sentido de esta actividad [literaria] consiste en que no está nunca donde se lo busca, ni se encuentra en el lugar donde podría estar. Hay un lugar vacío y hay el desplazamiento constante de una pieza: las teorías sobre la literatura son racionalizaciones de la insistencia de este juego de textos que se desplazan en el tiempo, que se superponen, se complementan o se anulan entre sí. En el cruce de un espacio reglado y un sujeto deseante que se somete a las leyes (literarias) para transgredirlas mejor, hay un constante desplazamiento que instituye reglas de juego para superar una entropía que siempre amenaza con instalarse en la página que se escribe $[. .$.$] . Entre esa página en blanco, ese vacío$ que me atrae y el texto que escribo hay la esperanza de la construcción de un objeto imposible y la amenaza de que la empresa naufrague en lo irrisorio. ${ }^{5}$

Neste sentido, ao nos propormos uma leitura que privilegie essa peça inexistente ou o vazio estruturante que potencia a entropia da obra, estamos contrapondo a um paradigma mimético e totalizante, embasado numa idéia de plenitude do ser, um paradigma da negatividade como pensamento limite para o objeto artístico, que somente deixa se entrever dentro duma lógica do intervalo ou da hiância constitutiva da subjetividade. Deste modo, mais do que tentar identificar uma unidade derradeira ou totalizadora da obra por trás dos textos de Levrero, nos propomos aqui simplesmente apontar ou sinalizar uma direção
4. BARTHES, Roland. Aula, 1978 , p.15.

5. GARCÍA, Leopoldo

Germán; GUSMAN, Luis; LAMBORGHINI, Osvaldo. "No matar la palabra, no dejarse matar por ella", 2011, p.11-12. 
6. Cf. RANCIÈRE, Jacques. A partilla do sensivel. Estética e Política, 2000.

7. ANTELO, Raul. Archifilologías latinoamericanas. Lecturas tras el agotamiento, 2015, p. 121-122.

8. Cf. LEVRERO, Mario. Historietas reunidas de Jorge Varlotta, 2016. que leve em conta esse elemento entrópico, a fim de rastrear ou escavar alguns vínculos possíveis entre os textos e outras formas ou objetos artísticos ou teóricos que nos permitam abrir o arquivo e ampliar a sua constelação de leituras. Assim, as noções de "cena" e "montagem" servirão como eixo transversal para operar com a leitura dentro de um regime de visibilidade da modernidade que Jacques Rancière ${ }^{6}$ conceitualizara como "estético", em contraposição a um regime "poético" ou "mimético". Como coloca Raul Antelo a respeito da relação entre as noções de cena e montagem para uma leitura potente da modernidade, no seu livro Archifilologías latinoamericanas:

[...] las escenas, los montajes heteróclitos, permiten de hecho desplazar el foco de análisis. Ya no es prioritaria la mimesis auerbachiana, sino la aisthesis, término que, en efecto, designa el modo de experiencia según el cual, en los últimos dos siglos, hemos percibido cosas muy diversas, con sus técnicas de producción y sus destinaciones en el campo del arte. No se trata de la recepción de obras específicas. Se trata del tejido de experiencia sensible al interior del cual esas obras han sido posibles. Son las condiciones materiales - lugares de performance y de exposición, formas de circulación y reproducción - pero también modos de percepción y regímenes de emoción, categorías que los identifican, esquemas de pensamiento que los clasifican e interpretan. Tales condiciones hacen posible que las palabras, formas, movimientos, ritmos sean percibidos y pensados como arte. ${ }^{7}$

Esboçados minimamente esses antecedentes críticos e teóricos detonantes deste trabalho, arriscamos uma possível entrada de leitura para o nosso problema: a noção e a relevância do desenho, do traço gráfico e da materialidade do gesto escritural como indicio sintomático por onde começar a rastrear uma genealogia da dessemelhança entre Levrero e este regime não figurativo das artes que atravessa a modernidade.

No passado ano de 2016, reuniu-se boa parte das tirinhas publicadas em vida por Jorge Mario Varlotta Levrero, em colaboração com Lizán ${ }^{8}$, em diversas revistas e suplementos esparsos no Rio da Prata, desde finais dos anos setenta até entrados os anos oitenta. Assim, além de reunir em um único volume publicações difíceis ou já impossíveis de se encontrar em livrarias e afins, esta esmerada edição traz à luz também uma boa quantidade de material inédito que se conserva no arquivo do escritor, ainda em fase de catalogação. Deste modo, resulta interessante observar neste material agora publicado a importância e a preponderância que o escritor dedicou ao desenho e ao humor gráfico desde os começos da sua produção. Neste sentido cabem destacar os esboços intitulados "De los elefantes y sus aconteceres", "La nueva lógica" e "Las aventuras del ingeniero Strudel" 
porque pode-se encontrar ali, de modo germinal, o trabalho paralelo entre desenho e escritura como parte de um mesmo processo criativo. Como podemos inferir das entrevistas reunidas e publicadas do escritor por Elvio Gandolfo", assim como do ensaio biográfico levado a cabo por Montoya Juárez ${ }^{10}$, a relação de Levrero com a escritura esteve sempre permeada por uma série de incursões na fotografia, o cinema e o desenho. Nestes textos-desenho, realizados por Levrero durante os anos setenta, é possível perceber uma proximidade ou afinidade plástica entre a letra e o traço gráfico que remetem a um experimentalismo com as formas e os suportes, numa mistura heteróclita difícil de qualificar claramente como simplesmente tirinhas ou puros desenhos. Ainda assim, é possível entrever nestes materiais como o trabalho com as imagens já se encontra no centro vertiginoso do seu processo criativo. Como escreve o autor, com motivo da publicação parcial de "Las aventuras del Ingeniero Strudel" no suplemento cultural Insomnia, no ano 2000, ao relembrar a "gênese" desses textos-desenho:

Esta serie se inició en Burdeos, no sé bien por qué. Sé que no podía escribir [...]. El hecho es que me puse a dibujar, y por suerte (porque dibujar es terapéutico) el impulso continuó al regreso [a Montevideo].

Quería hacer una historieta que más bien pudiera verse como un todo, de un solo golpe de vista; que en ese golpe de vista se captara todo el sentido (o sinsentido) de la historieta. Es decir, estaba pensando en términos plásticos; quería que pudiera mirarse como un cuadro. [...]

Después aparecieron las letras, al principio por la necesidad de dar tonos de gris al fondo blanco. [...] En realidad la idea era escribir incoherencias, incluso palabras sueltas o líneas que simularan la escritura manuscrita. ${ }^{11}$

Essa "inquietude plástica"12, ou vontade de chocar ou afetar o leitor-espectador, ligada ao trabalho com as imagens através do desenho e da escritura como procedimentos reversíveis ou suplementares dum mesmo processo criativo, aparentado com a pintura, o collage ou a montagem ${ }^{13}$, mas também com as formações do inconsciente e os mecanismos da memória, fazem parte da singularidade apresentada por Levrero ao longo de toda sua produção. Estas afirmações não apresentam nenhuma novidade se nos ativermos às numerosas declarações em entrevistas e em diversos momentos da sua obra, nos quais o escritor proclama uma narrativa "autêntica" cujo ponto de partida é invariavelmente a imagem. No entanto, a pesar dos diversos depoimentos do autor sobre seu próprio processo criativo e os seus avatares que incluem hipnotismo, parapsicologia e transe ${ }^{14}$, preferimos aqui nos concentrar no aspecto "originario" das imagens dentro de tal processo e tentar uma leitura que privilegie ou potencialize a dimensão estética, no sentido de um afeto ou pathos
9. Cf. GANDOLFO, Elvio. Un

silencio menos. Conversaciones con Mario Levrero, 2013.

10. Cf. MONTOYA, JUÁREZ, Jesús. Mario Levrero para armar. Jorge Varlotta y el libertinaje imaginativo, 2013.

11. Ibidem. p. 73.

12. Ibidem. p. 42.

13. Considerados como principios básicos de composição oriundos das práticas de vanguarda na arte (cubismo, surrealismo, dadaismo, cinema experimental, etc.), entendemos o collage e a montagem como procedimentos ou práxis complexas e correlatas, de extensa tradição teórico-crítica e de intrincadas e radicais consequências para a concepção de arte na modernidade. Sem poder abordá-los como merecem neste espaço, destacamos para nossa leitura o conceito de montagem, entendido básicamente como sintaxe ou arranjo de imagens descontinuas, e o uso dado por Didi-Huberman na desconstrução do discurso historicista a partir do trabalho de Walter Benjamin. Como diz Didi-Huberman: "Só se expõe - poética, visual, musical ou filosoficamente - a política ao mostrar os conflitos, os paradoxos, os choques recíprocos com os quais toda a história é tecida. É por isso que a montagem aparece como procedimento, por excelência, dessa exposição: as coisas só aparecem aí ao tomarem posição, elas só se mostram aí ao se desmontar inicialmente". E mais adiante: a "montagem é uma exposição de anacronismos naquilo mesmo que ela procede como uma explosão da cronologia. A montagem talha as coisas habitualmente reunidas e conecta as coisas habitualmente separadas. Ela cria, portanto, um abalo e um movimento [...] 
A explosão tendo acontecido, é um mundo de poeira - farrapos, fragmentos, resíduos - que, então, nos rodeia". DIDIHUBERMAN, Georges. "Remontar, Remontagem (do tempo)", 2016, p. 1; 6.

14. Cf. MARTÍNEZ, Luciana.

"Mario Levrero: parapsicología, literatura y trance", 2010, p. 33-58.

\section{Cf. DIDI-HUBERMAN,} Georges. "Imagen matriz. Historia del arte y genealogía de la semejanza", 2008, p. 101-136.

16. Clemente Padín, apud. MONTOYA JUÁREZ, Jesús. Mario Levrero para armar, 2013, p.42, (grifo nosso).

17. Cf. VARGAS GIORGI, Arthur de. "Arte Roschach". Outra Travessia, n, 19, 2015, p. 81-104.

18. "Médico graduado en la Universidad de Perugia, es enviado como oficial médico al norte de África durante la Segunda Guerra Mundial. En 1943 las fuerzas norteamericanas lo trasladan como prisionero al campo de Heresford, en Texas, donde comienza a pintar. Las primeras obras incluyen telas rotas y pintura roja que simula sangre. Cuando lo liberan, en 1946, se traslada a Roma donde expone en la galería Margherita. En 1948, en su segunda exposición en la misma galería, sus obras son completamente abstractas. Inicia un período de intensa experimentación con los materiales que desarrolla en varias series (Composizione, Catrame, Bianchi, Muffi, Sacchi, Sabbia, Gobbi, Combustioni, Legni). [...] Las obras de Burri coordinan materiales de desecho, pintura, números, marcas. Las paletas en rojo y negro, junto a las texturas de los materiales remiten a la sangre, el fuego, las heridas, la violencia. Sus técnicas expresan una urgencia, provocado pelo contato entre as imagens ${ }^{15}$, inerente à configuração da arte como pensamento paradoxal na modernidade.

Neste sentido, resulta interessante a declaração em entrevista do artista visual Clemente Padín, amigo do escritor e diretor da revista Los Huevos del Plata, na qual aparece publicado um dos seus primeiros relatos, "Gelatina", em 1968, sobre a latência desta "inquietude plástica" que tentamos destacar em Varlotta-Levrero:

En una ocasión me insistió en que debía ir a su apartamento en la calle Soriano, un lugar lúgubre, por cierto [...] que tenía que ver una obra que había hecho. En una de las paredes de la pieza había escrachado comida y diferentes cosas que habían manchado la pared [...] después vi obras vinculadas al punk en los ochenta, cuando estuve en Berlín, que eran muy parecidas a lo que vi en su casa [...]. Yo creo que Varlotta nunca conoció nada de eso [...] (pero me pareció después) una anticipación, cierto informalismo pictórico. ${ }^{16}$

Surgida no imediato pós-guerra na Europa, Estados Unidos e Japão, mas com impactos transatlânticos nas neo-vanguardas na Argentina e no Brasil ${ }^{17}$, esta tendência pictórica informalista, também denominada abstração lírica, expressionismo abstrato ou tachismo, foi detectada primeiramente pelo escritor e crítico Michel Tapié, quem em 1952 acunha o termo art autre para dar título a uma exposição que reunia nomes como Karen Appel, Jean Dubuffet, Willem de Kooning e Alberto Burri, entre outros. Sob o signo da destruição, da ruptura e do desencanto com as tradições de ordenação e composição figurativas ou da abstração geométrica modernistas, estes artistas propõem, desde diversas técnicas e procedimentos (como o collage, a sutura, o corte, a solda ou a perfuração) uma preocupação com as possibilidades expressivas da matéria (gênero, papel, madeira, metal, lâminas plásticas, areia, etc.), assim como da gestualidade, a espontaneidade e o papel do acaso e da improvisação no trabalho do artista, dando lugar a um ato criador performático no qual a forma desaparece como elemento significante e acabado. A modo de exemplo, para nossa leitura, reproduzimos a seguir duas obras de artistas ditos informalistas: uma de Alberto Burri ${ }^{18}$ e a outra de Kenneth Kemble ${ }^{19}$ : 


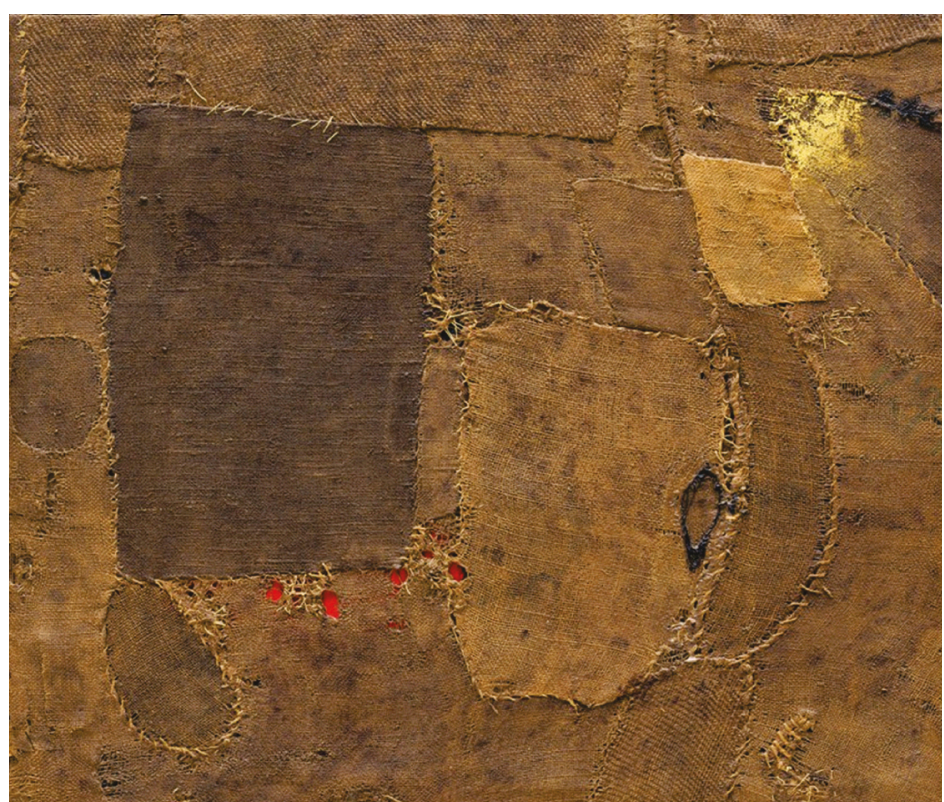

Fig. 1: Alberto Burri, Composizione, 1953

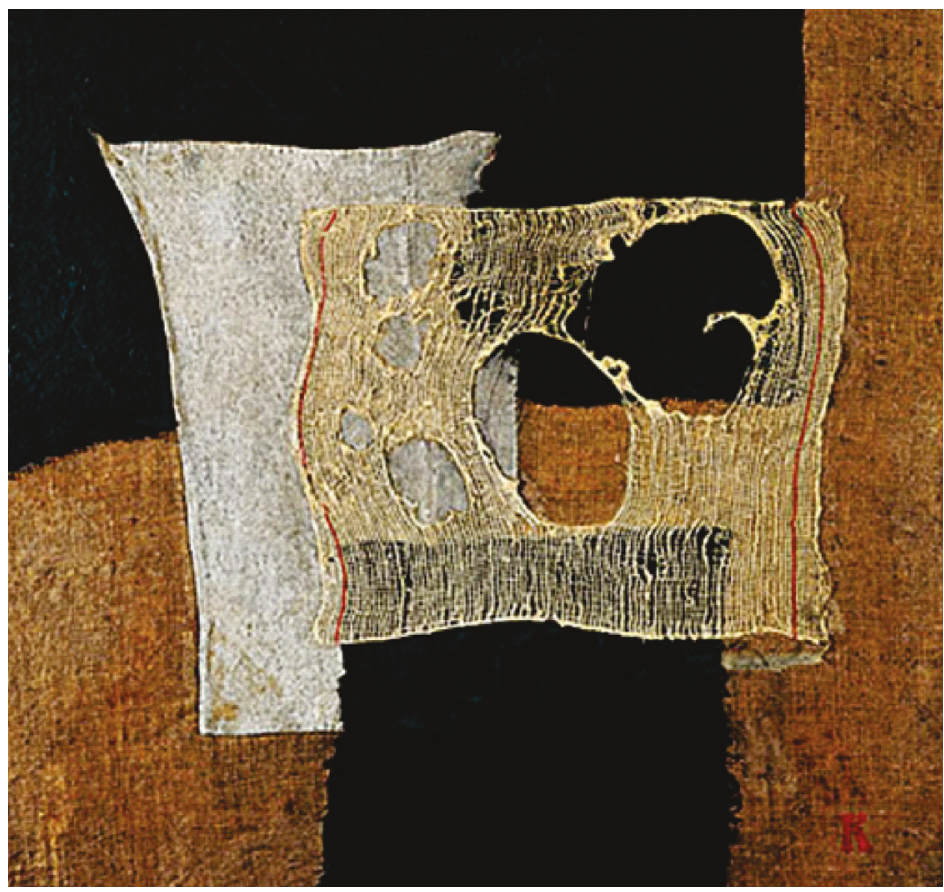

Fig. 2: Kenneth Kemble, Composición con trapo y rejilla, (técnica mista), 1958

Em relação às imagens como disparadoras de um processo composicional e criativo que segue mecanismos próximos aos das formações do inconsciente e da memória em Levrero, cabe comentar a sua nouvelle "Los muertos", incluída no volume de contos Espacios libres. Esse texto resulta paradigmático na hora de tentar entrever essa "lógica do contato" e da impressão táctil que governa os saltos e a montagem das cenas, construídas em torno duma semelhança impura ou deslocada entre as imagens. son texturas brutales que buscan un efecto inmediato. El uso de materiales encontrados, que portan las marcas del tiempo, el deterioro, el abandono, influyó en la generación siguiente de artistas italianos cuya propuesta se conoce como arte povera. [...] La obra de Burri fue revisitada por los artistas argentinos, particularmente por Kenneth Kemble y Mario Pucciarelli, y en general por los informalistas. Este contacto puede incluso vincularse con los materiales de desecho que Berni incorporó en sus collages desde fines de los años cincuenta y que juegan un rol protagónico en las series de Juanito Laguna”. GIUNTA, Andrea. "Comentario sobre Combustione E.I", s/d.

19. "Kenneth Kemble fue uno de los protagonistas de un momento bisagra para el arte argentino que tuvo lugar entre el año 1956 y los primeros años de la década del sesenta, cuyos ejes conceptuales fueron la idea de "muerte del arte" y la desintegración del objeto artístico tradicional. Autor de la idea y organizador de la exposición Arte destructivo (1961), netamente rupturista y experimental, Kemble había optado desde 1956 por el collage como uno de sus medios artísticos predilectos incorporando a la obra diversos materiales considerados hasta ese momento extra-artísticos, tales como papel de lija, trapos rejilla, ropa interior de mujer manchada, chapas, maderas, arpilleras, clavos y vidrios, entre otros, todos con las correspondientes huellas del tiempo y del uso. Sus obras producidas entre 1956 y 1963 corresponden a lo que Marcelo Pacheco ha llamado la "gran ruptura". A partir de 1963 el desarrollo de Kemble tuvo un carácter más llano, y aunque pasó por diferentes etapas ya no 
produjo rupturas tan radicales. Sin embargo, el collage continuó siendo una de sus modalidades artísticas más recurrentes, que Kemble combinó con un tipo de realización más compleja". CASANEGRA, Mercedes. "Comentario sobre Pintura abstracta con connotaciones de danza", s/d.

20. LEVRERO, Mario. Espacios libres, 1987, s/p.

21. Cf. GELLES, Soledad. "Una lectura de Los muertos de Mario Levrero", 1996, p. 73-79.

22. LEVRERO, Mario. Espacios libres, 1987, s/p.
O relato trama-se em torno de um personagem-narrador que se debate interiormente perante a súbita "presença-ausente" do cadáver de um estranho suicida na antiga casa onde vive com suas tias. O texto se constrói em base a constantes saltos e superposições de cenas, entre a impressão e a memória, entre a percepção sensorial e as dobras da interpretação, entre o detalhe nímio e sua ampliação extrema, explícitas na voz do personagem-narrador, subsumido numa espécie de policial paranóico ou psicanalítico. Assim, por exemplo, à evidencia sensível do estranho cadáver no "quarto do piano" da casa, o narrador-personagem superpõe-lhe um périplo de associações que começam por sobrepor a "visão" de um outro cadáver, intuído no momento do disparo, que cai constantemente em cima do primeiro:

Allí [...] comenzó el otro problema, el de la superposición;
por algún motivo se me mezcló la imagen intuida con
lo que estaba viendo, y fue como si otro inquilino se
pegara un tiro delante de mis ojos y cayera atravesado
sobre el primer cadáver, y ahora tenía dos cadáveres para
preocuparme, uno real y el otro no, [...] de ahí en adelante
no podía pensar en "el muerto", sino en "los muertos", y
me imaginaba haciendo declaraciones confusas. ${ }^{20}$

No entanto, não é seguindo esse aspecto do narrador-personagem que duvida ou conjetura, à maneira de um detetive freudiano, em torno de como proceder perante esse Unheimlich e as autoridades familiares ou policiais, o que queremos destacar neste texto ${ }^{21}$. Assim, ainda que a "presença-ausente" do cadáver constitua o centro vazio ou enigmático da trama do relato, é o procedimento narrativo embasado na montagem e o choque de cenas que gostaríamos de ressaltar neste momento. Neste sentido, há varias remissões à atividade onírica e imaginativa que conformam uma rede tanto textual como metatextual configurando a nouvelle. Como coloca o narrador-personagem perante o dilema de fazer ou não a denúncia telefônica sobre o acontecido na casa:

Lo que realmente quería hacer, de todo corazón, era echarme a dormir. Durmiendo es como encuentro las mejores ideas para resolver situaciones difíciles, y muy a menudo las situaciones difíciles se resuelven solas mientras duermo; uno está demasiado consustanciado con la noción de actividad $[\ldots]$ a pesar de la advertencia de Lao Tsé hace ya tantos siglos. ${ }^{22}$

Assim também, a memória e a imaginação como faculdades das semelhanças dissímeis aparecem no texto associadas com a noção do contato sensível e da impressão tátil como mecanismos de uma escritura embasada na imagem e a montagem. 
Deste modo, partindo de uma sensação de "náusea" ou mal-estar inicial a respeito da situação na casa, o narrador-personagem deriva outra série de associações que envolvem sonhos, lugares e detalhes heterogêneos ou anacrônicos que conformam o relato como uma espécie de arqueologia onírica:

No era la primera vez que me veía en una situación similar, aunque la similitud se dé más bien en mi percepción de las cosas y no tanto en los hechos concretos - siempre superficiales. Ahora me sentía con un estado de ánimo y con una sensación física, casi de náusea, como calcados de la otra ocasión, cuando en un atardecer, también en verano, se dio algo tan particular con una mujer llamada Frieda. ${ }^{23}$

Sendo assim, a narrativa se constrói como escavação de imagens e detalhes que ultrapassam a mera descrição "ecfrástica" como procedimento de representação geral ${ }^{24}$ do material inconsciente. Mais do que isto, o texto performa como gesto na escritura os próprios paradoxos associados à memória e ao pensamento da arte na modernidade, ou ao seu "regime estético", e poderiam derivar numa concepção anacrônica da História. A respeito desse presente ultra-histórico, concentrado numa concepção do devir histórico como "imagem dialética" que convoca à tarefa do historiador ou do filólogo a uma suspensão ou demora do tempo cronológico, numa explosão significante capaz de arrancar a época da sua continuidade coisificada de tempo homogêneo, nos diz Raul Antelo:

[...] la memoria no es un instrumento para la exploración del pasado, sino solamente un medio para ello, porque así como la tierra es el medio en que yacen enterradas las viejas ciudades, la memoria es también el medio de lo vivido. Quien intenta acercarse a su propio pasado sepultado tiene que comportarse como un hombre que excava. Cava y excava su propio mundo, que no existe antes o más allá de ese gesto. No debe temerle volver siempre a la misma situación y esparcirla como se esparce la tierra, revolverla como se revuelve la tierra. Porque las situaciones no son nada más que capas que sólo después de una investigación minuciosa dan a luz lo que hace que la excavación valga la pena, es decir, las imágenes que, arrancadas de todos sus contextos anteriores, aparecen como auténticos objetos de valor en los sobrios aposentos de nuestra comprensión tardía, como torsos en la galería del coleccionista. ${ }^{25}$

Neste sentido, surge também a idéia do escritor ou do artista moderno como aquele encarregado de fazer falar as coisas mudas, através dos detalhes e dos vestígios invisibilizados por uma ordem da representação que privilegia um saber consagrado ao $\log o s$ e à racionalidade empírico-positivista, em detrimento do pathos ou do afeto secreto latente nas dobras da sua própria
23. Ibidem, s/p.

24. Cf. MONTOYA JUAREZ, Jesús. "Narraciones a base de imágenes: una lectura de Los muertos", 2013.

25. ANTELO, Raul. Archifilologías latinoamericanas. Lecturas tras el agotamiento, 2015, p. 12. 
historicidade como mitologia, fantasma ou imagem. Como coloca Jacques Rancière em O inconsciente estético:

O artista é aquele que viaja nos labirintos ou nos subsolos do mundo social. Ele recolhe os vestígios e transcreve os hieróglifos pintados na configuração mesma das coisas obscuras ou triviais. Devolve aos detalhes insignificantes da prosa do mundo sua dupla potência poética e significante. $\mathrm{Na}$ topografia de um lugar ou na fisionomia de uma fachada, na forma ou no desgaste de uma vestimenta, no caos de uma exposição de mercadorias ou de detritos, ele reconhece os elementos de uma mitologia. E, nas figuras dessa mitologia, ele dá a conhecer a história verdadeira de uma sociedade, de um tempo, de uma coletividade; faz pressentir o destino de um indivíduo ou de um povo. Tudo fala, isso quer dizer também que as hierarquias da ordem representativa foram abolidas. A grande regra freudiana de que não existem "detalhes" desprezíveis, de que, ao contrário, são esses detalhes que nos colocam no caminho da verdade,

26. RANCIÈRE, Jacques. $O$ inconsciente estético, 2009, p. 36

27. Neste sentido, resulta interessante ressaltar que esse trecho é citado pelo próprio escritor em entrevista como exemplo de seu processo criativo a partir de imagens. Ver: VERANI, Hugo. "Conversación con Mario Levrero”, 1996, p. 7-17.

Continuando com a leitura da nowvelle, o começo do capítulo 4 se apresenta como paradigmático de tudo quanto viemos colocando até aqui: o relato como imagem caleidoscópica feita de restos, detalhes, deslocamentos e ampliações através da montagem e da repetição diferida de uma impressão "originaria" que, perdida desde sempre, não deixa de voltar como o fantasma do estrangeiro, do estranho cadáver "presente-ausente" dentro de casa da tradição, como identidade de contrários, como pathos e logos no centro vazio da cena do crime. Irrompendo como um enxerto numa peça de collage com o capítulo anterior, ambientado com o narrador-personagem nas ruas se debatendo em torno da possível identidade do estrangeiro suicida, a seguinte cena $^{27}$ resulta numa verdadeira quebra anacrônica, uma ruptura que deixa ao descoberto um procedimento metaficcional e um pensar paradoxal sobre o próprio objeto artístico:

Hay un dibujo que se va formando, lleno de palabras, o es tal vez un discurso cuyas palabras se ordenan formando un dibujo. Al principio todo es confuso y obscuro, luego aparece un bulto que se va revelando como integrado por capas, algo como telas dibujadas, pegoteadas entre sí, húmedas y apelotonadas, y debo tener la paciencia de irlas despegando una a una sin que se dañen; esto puede llevar mucho tiempo o incluso no suceder nunca; yo no soy realmente quien opera sino apenas un espectador casi pasivo: mi única actividad consiste en mantener la atención puesta en ese transcurrir, tratando de eliminar interferencias.

Ese pegote de telas tiene un olor particular, a humedad, a cosa antigua, y al mismo tiempo es como si el olor formara parte del discurso y del dibujo; así, cuando se me pierde 
uno o el otro, sigo el rastro por medio del olfato. El dibujo insinuado en lo que puede verse por ahora en algunas de esas telas es, probablemente, el mismo o muy parecido al formado por el terciopelo, con distintos tonos de gris, marrón y negro, en el tapizado de los sillones de la sala de mis tías $[\ldots]$.

El dibujo del tapizado es precisamente una flor, pero heráldica; una flor de lis de mediano tamaño, repetida varias veces. Casi puedo acariciar ese terciopelo, siguiendo el contorno de la flor con la yema de los dedos, y ya no es el olor, ni el discurso, ni el dibujo, sino tal vez el tacto, o más probablemente otra cosa que por ahora no puedo definir, apoyada en una impresión de origen táctil, que también se integra al cuadro general de la sala del piano.

La flor de lis repetida no es el único dibujo; hay otros trazos, adornos, arabescos, en un gris menos contrastado. Por momentos esos trazos parecen formas de escritura, pero no son ésas las palabras del discurso, o si coinciden con éstas no puedo saberlo, no conozco el significado. Las palabras del discurso son formuladas mentalmente, y sólo adquieren cuerpo y un sentido preciso cuando se ajustan a las sugerencias de los dibujos y de los olores; pero así y todo no sería capaz de repetirlas: sólo ahora, mucho más tarde, puedo tratar de reconstruirlas con otras palabras para indicar el clima del discurso, no las palabras mismas ni su significado exacto, que siempre se me pierden.

Así los dibujos y las palabras me llevan como por piezas contiguas que sin embargo son la misma pieza; sin duda una habitación interior, algo mío, expresándose en diferentes imágenes y sensaciones. Y así, sintiendo en mí una cierta excitación, fui recobrando el clima y las imágenes del sueño del supermercado, porque allí había un museo y ese museo tenía mucho de la pieza del extranjero - la sala de mis tías. ${ }^{28}$

Esse trecho, além de resultar central na economia do relato por abrir outros desvios mnêmicos e oníricos que deflagrarão o "final", põe em relevo e coloca sobre a mesa a dinâmica pré-escrituraria da qual viemos tratando. A partir duma "lógica do contato" entre as imagens associadas por dessemelhança, oriunda dos mecanismos da memoria e dos sonhos, essa dinámica faz parte também de uma produtividade do "inconsciente estético" moderno; misto das ordens entre artes puras e artes aplicadas num mesmo movimiento de transposicão sinestésica entre o visual e o táctil, entre a representação "ecfrástica" da imagen e o traço abstracto ou decorativo. Como explica Jacques Rancière, é nesta interface de suportes entre escritura e imagem na qual se gesta uma nova "partilha do sensível", que virá a quebrar a hegemonia da representação mimética na modernidade e abrirá espaço a uma potência heterogênea do pensamento na arte, colocando em questão as relações entre estética e política, pois
28. LEVRERO, Mario. Espacios libres, 1987, s/p. 
29. RANCIÈRE, Jacques. $O$ inconsciente estético, 2009, p. 20-23.

30. Neste sentido, resultam interessantes as considerações sobre o desenho levantadas pelo "último" Mario de Andrade num breve artigo escrito em 1945 intitulado "Do desenho". No mesmo, o crítico e escritor traça uma arqueologia do conceito de escritura a partir do desenho através de um prisma não ocidental (caligráfico) desta arte, assinalando ao mesmo tempo seu caráter aberto e transitório entre as artes do espaço (pintura) e as artes do tempo (literatura) chegando até compará-lo com a dança. (Notas de aula do dia 17/09/2014 na disciplina "O literário como dispositivo discursivo", ministrada pelo professor Raul Antelo na Universidade Federal de Santa Catarina.)

31. SARDUY, Severo. Escrito sobre um corpo, 1979, p. 48. um papel tão importante no Renascimento e que vinhetas, fundos de lâmpada e inovações diversas da tipografia romântica ressuscitaram. Esse modelo embaralha as regras de correspondência à distância entre o dizível e o visível, próprias à lógica representativa. Embaralha também a partilha entre as obras da arte pura e as decorações da arte aplicada. É por isso que teve um papel tão importante - e geralmente subestimado - na transformação radical do paradigma representativo e nas suas implicações políticas. Penso principalmente em seu papel no movimento Arts and Crafts e todos seus derivados (Art Déco, Bauhaus, construtivismo) em que se definiu uma ideal do mobiliário - no sentido amplo - da nova comunidade, que também inspirou uma nova ideia da superfície pictural como superfície de escrita comum. [...]

É na superfície plana da página, na mudança de função das "imagens" da literatura ou na mudança do discurso sobre o quadro, mas também nos entrelaces da tipografia, do cartaz e das artes decorativas, que se prepara uma boa parte da "revolução antirrepresentativa" da pintura. Esta pintura, tão mal denominada abstrata e pretensamente reconduzida a seu médium próprio, é parte integrante de uma visão de conjunto de um novo homem, habitante de novos edifícios, cercado de objetos diferentes. Sua planaridade tem ligação com a da página, do cartaz ou da tapeçaria - é uma interface. E sua "pureza" antirrepresentativa inscreve-se num contexto de entrelaçamento da arte pura e da arte aplicada, que lhe confere de saída uma significação política. ${ }^{29}$

Por outro lado, e voltando ao trecho citado, esse movimento faz com que a escritura mostre seu duplo estado "original" entre o desenho e a letra, como ideograma que concentra num só gesto uma constelação pluridimensional impossível de ser remetida a uma totalidade puramente logocêntrica ou representacional, exterior ao texto e na qual caberia encontrar um significado ou compreensão única. Mais do que isto, se toda mimese realista necessita de uma moldura e um fundo no qual limitar a representação do visível e do dizível, essa dupla natureza pictográfica da escritura aparentada com o desenho quebra qualquer enquadramento a priori, e participa de um movimento de disseminação do significante como traço ou inscrição que já poderíamos encontrar na arte dos povos primitivos, na tatuagem dos corpos ou na decoração dos seus objetos ${ }^{30}$.

É, portanto, nesta distância estabelecida entre significante e significado, na dissociação entre semântico e semiótico, numa abertura na qual o "fundo" da obra como ausência se torna uma "superfície" que não designa nada mais alem de um "lugar sem limites, [um] espaço de conversões, de transformações e disfarces: o espaço da linguagem" ${ }^{31}$ que o artista se aproxima do tatuador e a literatura de uma arte da tatuagem, pois esta 
[...] inscreve, cifra na massa amorfa da linguagem informativa os verdadeiros signos da significação. Mas essa inscrição não é possível sem ferida, sem perda. Para que a massa informativa se converta em texto, para que a palavra comunique, o escritor tem que tatuá-la, que inserir nela seus pictogramas. A escritura seria a arte desses grafos, do pictural assumido pelo discurso, mas também a arte da proliferação. A plasticidade do signo escrito [...] está presente em toda literatura que não esqueça sua natureza de inscrição, o que se poderia chamar escrituralidade. ${ }^{32}$

Enfim, acreditamos que poderia ser através deste gesto "sem descendência" do desenho, não mimético e fechado, porém mímico e aberto, o qual não tende a uma totalidade e sim ao fragmento, à dispersão, ao puro movimento do traço sem significação a priori num entre-lugar entre o arcaico e o moderno, no qual se jogue em Levrero aquele elemento entrópico mencionado no começo. Ao mesmo tempo, esse gesto poderia ser tomado como uma impugnação do literário ao existente, ao dado ou a qualquer síntese que tente estabilizar a potência heterogênea da escritura, cuja cifra somente pertence às leituras por vir.

\section{Referências}

ANDRADE, Mario de. "Do desenho". In: Aspectos das artes plásticas no Brasil. São Paulo: Livraria Martins Editora, 1966. p. $71-77$

ANTELO, Raul. Archifilologías latinoamericanas. Lecturas tras el agotamiento. Córdoba: Eduvim, 2015.

BARTHES, Roland. Aula. Tradução e posfácio Leyla PerroneMoisés. São Paulo: Cultrix, 1978.

CASANEGRA, Mercedes. "Comentario sobre Pintura abstracta con connotaciones de danza". MNBA, Buenos Aires, s/ d. Disponível em: https://www.bellasartes.gob.ar/coleccion/ obra/9411. Acesso em: 08/08/2017.

DE ROSSO, Ezequiel. "Otra trilogía: las novelas policiales de Mario Levrero". In: . (Org.) La máquina de pensar en Mario. Ensayos sobre la obra de Levrero. Buenos Aires: Eterna Cadencia, 2013.

DIDI-HUBERMAN, Georges. Ante el tiempo. Historia del arte y anacronismo de las imágenes. Tradução e nota preliminar de Antonio Oviedo. Buenos Aires: Adriana Hidalgo, 2008.
32. Ibidem. p. 53-54 
"Remontar, Remontagem (do tempo)". Tradução Milene Migliano. Caderno de Leituras. n.47. Edições Chão de Feira, 2016. Disponível em: http:// chaodafeira.com/ wp-content/uploads/2016/07/cad_47.pdf. Acesso em: 04/08/2017.

FUENTES, Pablo. "Estudio posliminar. Levrero: el relato asimétrico". In: LEVRERO, Mario. Espacios libres. Montevideo: Puntosur, 1987;

GANDOLFO, Elvio (Org.) Un silencio menos. Conversaciones con Mario Levrero. Buenos Aires: Mansalva, 2013.

GARCÍA, Leopoldo Germán; GUSMÁN, Luis; LAMBORGHINI, Osvaldo. "No matar la palabra, no dejarse matar por ella". Literal. Edición facsimilar. Buenos Aires: Biblioteca Nacional, 2011.

GELLES, Soledad. "Una lectura de Los muertos de Mario Levrero". Nuevo Texto Crítico. vol. III, n. 16/17. California: Standford University, 1996, p.73-79.

GIUNTA, Andrea. "Comentario sobre Combustione E.I". MNBA, Buenos Aires, s/ f. Disponível em: https://www. bellasartes.gob.ar/coleccion/obra/7984. Acesso em: 08/08/2017.

GORTAZAR, Alejandro. "El canon nacional por dentro y por fuera. Felisberto Hernández en las antologías narrativas uruguayas (1930-1966)". Fragmentos. n.19. Florianópolis: Editora UFSC, 2000, p.31-45.

LEVRERO, Mario. Espacios libres. Montevideo: Puntosur, 1987. El discurso vacio. Montevideo: Trilce, 2004. Irrupciones. Montevideo: Criatura, 2013. Historietas reunidas de Jorge Varlotta. Montevideo: Criatura, 2016.

MARTÍNEZ, Luciana. "Mario Levrero: parapsicología, literatura y trance". Los límites de la literatura. Rosario: Centro de Estudios de Literatura Argentina, 2010, p.33-58.

MONTOYA JUAREZ, Jesús. Mario Levrero para armar. Jorge Varlotta y el libertinaje imaginativo. Montevideo: Trilce, 2013.

OLIVERA, Jorge. Intrusismos de lo real en la narrativa de Mario Levrero. Tesis doctoral. Madríd: Universidad Complutense, 2008.

RAMA, Ángel. "Prólogo”. In: . Aquí cien años de raros.

Montevideo: Arca, 1966. 
RANCIÉRE, Jacques. A partilha do sensivel: Estética e Política.

Tradução Mônica Costa Netto. São Paulo: Editora 34, 2000.

O inconsciente estético. Tradução Mônica Costa Netto. São

Paulo: Editora 34, 2009.

SARDUY, Severo. Escrito sobre um corpo. Tradução Lígia

Chiaprinini M. Leite e Lúcia Teixeira Wisnik. São Paulo:

Editora Perspectiva, 1979.

VARGAS GIORGI, Arthur de. "Arte Roschach”. Outra

Travessía. N. 19, p. 81-104, 2015.

VERANI, Hugo. "Conversación con Mario Levrero". Nuevo

Texto Crítico, vol. III, n. 16/17. California: Standford University, p. 7-17, 1996

Submissão: 09/05/2017

Aceite: 13/12/2017 